\title{
Special Issue on Global Land Product Validation
}

\section{OVERVIEW of the Special ISSUE ON Global LAND PRODUCT VALIDATION}

I $\mathrm{N}$ PARALLEL with the recent bloom of sensors providing frequent medium-resolution observations (Fig. 1), global land products have been increasingly developed and released within the community. The raw data acquired by these sensors are transformed into higher level products that can be more easily exploited by the user community. In many cases, multiple products are developed from each sensor and similar products derived from different sensors. With this, users need access to quantitative information on product uncertainties to help them assess the most suitable product, or combination of products for their specific needs. As remote sensing observations are generally merged with other sources of information or assimilated within process models, evaluation of product accuracy is required. Making quantified accuracy information available to the user can ultimately provide developers the necessary feedback for improving the products, and can possibly provide methods for their fusion to construct a consistent long-term series of surface status.

The Committee on Earth Observation Satellites (CEOS) established a working group on Calibration and Validation (WGCV) in 1984. Initially, this group focused on wavelength-specific calibration issues. However, as CEOS members started to develop higher order products, there grew the need to direct some CEOS WGCV activity toward the validation of these products. With this, in 2000, the Land Product Validation (LPV) subgroup was established under WGCV in recognition of the need for, and benefits of, international land product validation coordination (http://lpvs.gsfc.nasa.gov/). The LPV subgroup's mission is to foster quantitative validation of higher-level global land products derived from remote sensing data. This is being achieved through the following three specific objectives:

1) facilitating international cooperation and coordination of validation activities by sharing information on instruments, analyses, and field activities;

2) increasing the quality and economy of land product validation by developing standards and protocols for field sampling, error budgeting, data exchange, and product evaluation;

3) providing a forum for discussion of current issues and for exchange of technical information on efficient approaches to global validation.

During the August 2004 workshop on the validation of Leaf Area Index products [3], it was decided that a special issue on global land product validation was warranted, resulting in this IEEE special issue designed to contribute to the three specific objectives.

Overview and framework topics related to the first objective are presented within three papers (Harold et al., Morisette et al.,

This work was supported in part by the National Aeronautics and Space Administration under Grants EOS/03-0408-0637 and NNG04GL85G.

Digital Object Identifier 10.1109/TGRS.2006.877436

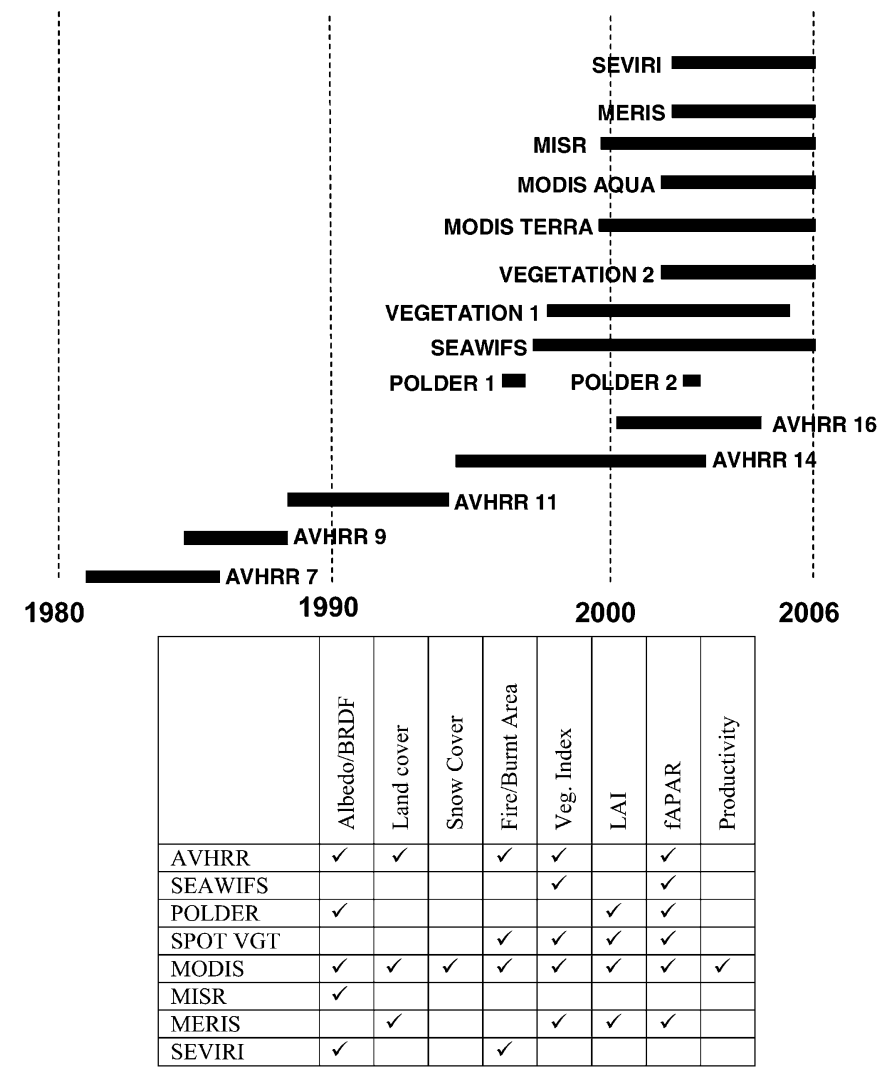

Fig. 1. Medium-resolution Earth observing sensors covering the last 25 years and the standard, higher level land products available for current sensors. Note that for a single sensor, several products may exist.

Baret et al.). A series of 19 product validation papers address the second objective by describing the acceptable practices for quantifying the accuracy of the global products covered in these papers. Finally, to achieve the third objective, papers were solicited to present the user perspective on how accurate the products need to be, why it is important to quantify the uncertainty, and how closely the available products meet those needs. This resulted in four special issue communications related to the user response. Table I lists the papers in this special issue broken down by sensor and product.

\section{VALIDATION STAGES}

The papers in this special issue show various stages of validation for multiple global land products. It is difficult to answer strictly "yes" or "no" to the question of whether a product been validated or not. With this, and in recognition of the cost and effort involved in global product validation, CEOS, through the work and consensus of LPV, has defined the following validation hierarchy for global land products.

Stage 1 Validation: Product accuracy has been estimated using a small number of independent measurements obtained from selected locations, time periods, and ground-truth/field program efforts. 
TABLE I

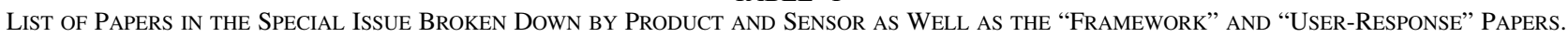
Note That All Refernces Are to This SPecial Issue AND Do nOt All APPEAR IN the Refernce List

\begin{tabular}{|c|c|c|c|c|c|c|c|c|}
\hline \multirow[b]{2}{*}{ Sensor } & \multicolumn{8}{|l|}{ Product } \\
\hline & BRDF & Land Cover & Snow & $\begin{array}{l}\text { Fire \& } \\
\text { Burnt Area }\end{array}$ & $\begin{array}{l}\text { Vegetation } \\
\text { Index }\end{array}$ & fAPAR & $\begin{array}{l}\text { Leaf Area } \\
\text { Index }\end{array}$ & Productivity \\
\hline MISR & $\begin{array}{l}\text { Abdou et al. } \\
\text { Lyapustin et al. }\end{array}$ & & & & & & & \\
\hline MODIS & & $\begin{array}{l}\text { Cohen et al. } \\
\text { See et al. }\end{array}$ & $\begin{array}{l}\text { Salomonson } \\
\text { et al. }\end{array}$ & $\begin{array}{l}\text { Csiszar et al. } \\
\text { Boschetti et al. }\end{array}$ & $\begin{array}{l}\text { Brown et al. } \\
\text { Fensholt et al. }\end{array}$ & $\begin{array}{l}\text { Steinberg et } \\
\text { al. } \\
\text { Yang et al. } \\
\text { Yang et al. (2) }\end{array}$ & $\begin{array}{l}\text { Pandya et al. } \\
\text { Huang et al. } \\
\text { Abuelgasim et al. } \\
\text { Yang et al. (2) } \\
\text { Cohen et al. }\end{array}$ & $\begin{array}{l}\text { Turner et al. } \\
\text { Heinsch et al. }\end{array}$ \\
\hline SPOT VGT & & $\begin{array}{l}\text { Mayaux et al. } \\
\text { See et al. }\end{array}$ & & & Brown et al. & & Abuelgasim et al. & \\
\hline POLDER & & & & & & & Abuelgasim et al. & \\
\hline AVHRR & & & & & Brown et al. & & & \\
\hline SeaWiFS & & & & & Brown et al. & & & \\
\hline MERIS & & & & & Fensholt et al. & & & \\
\hline Framework & & Herold et al. & & & Baret et al. & & $\begin{array}{l}\text { Morisette et al. } \\
\text { Baret et al. }\end{array}$ & Baret et al. \\
\hline Response & & Lambin et al. & & Roy et al. & $\begin{array}{l}\text { van Leeuwen } \\
\text { et al. }\end{array}$ & & & $\begin{array}{l}\text { Plummer } \\
\text { Xiao }\end{array}$ \\
\hline
\end{tabular}

Stage 2 Validation: Product accuracy has been assessed over a widely distributed set of locations and time periods via several ground-truth and validation efforts.

Stage 3 Validation: Product accuracy has been assessed, and the uncertainties in the product well-established via independent measurements made in a systematic and statistically robust way that represents global conditions.

This special issue presents the current status of international validation activities. The 19 product validation papers provide results leading to stage one through three validation. The three framework papers (see Table I) demonstrate how emerging activities are gathering significant contributions from several institutions working toward stage two and stage three validation. At any stage, the feedback from the user community is essential, calling for open and easy access to all products and their accuracy estimates. The four user-response papers provide an example of such feedback. We believe this special issue reflects a snapshot of ongoing communication efforts within the community of global land product providers and users. The set of papers within this special issue help define where we are along the path of validation.

The outcome of the validation efforts presented in the special issue and continued work on global land products can lead to recommendations for the best use of current products and inform the design of future missions, both for the space and ground segments. This will ensure continuous improvement in our monitoring and understanding of the Earth.

\section{JEFFREY T. MORISETTE}

NASA Goddard Space Flight Center Greenbelt, MD 20771 USA

FRÈDÉRIC BARET

INRA-CSE Agroparc

84914 Avignon, France

SHUNLIN LIANG

University of Maryland

Department of Geography

College Park, MD 20742 USA

\section{ACKNOWLEDGMENT}

The work of the CEOS Land Product Validation subgroup in general, and this special issue, in particular, are based on several key CEOS members' commitment to validation. We are particularly grateful for the leadership and direction provided by Alan Belward, Chris Justice, and Jeff Privette, who were all instrumental in establishing the LPV subgroup. Funding for LPV efforts at NASA, including Morisette's role and the publication costs associated with this special issue, were provided by NASA's Terrestrial Ecology program (Diane Wickland, program manager) and the Land Cover Land Use Change program (Garik Gutman, program manager). We are grateful for support provided by these programs. Many individuals have contributed to work of LPV, through community workshops, authoring papers contained in this special issue, or providing reviews of these papers. Special thanks are extended to Ranga Myneni who helped in the formulation of this special issue.

\section{REFERENCES}

[1] F. Baret, J. Morisette, R. A. Fernandes, J. L. Champeaux, R. B. Myneni, J. Chen, S. Plummer, M. Weiss, C. Bacour, S. Garrigues, and J. E. Nickeson, "Evaluation of the representativeness of networks of sites for the global validation and intercomparison of land biophysical products: Proposition of the CEOS-BELMANIP," IEEE Trans. Geosci. Remote Sens., vol. 44, no. 7, pp. 1794-1803, Jul. 2006.

[2] M. Herold, C. Woodcock, A. Di Gregorio, P. Mayaux, A. Belward, J. Latham, and C. Schmullius, "A joint initiative for harmonization and validation of land cover datasets," IEEE Trans. Geosci. Remote Sens., vol. 44, no. 7, Jul. 2006.

[3] J. T. Morisette, J. L. Privette, J. Nickeson, F. Baret, R. B. Myneni, and N. Shabanov, "Summary of the Third International Workshop on LAI Product Validation, , Earth Obs., vol. 16, no. 5, pp. 28-31, Sep./Oct. 2004. [Online]. Available: http://eospso.gsfc.nasa.gov/eos_ observ/pdf/Sept-Oct04.pdf.

[4] J. T. Morisette, F. Baret, J. L. Privette, R. B. Myneni, J. Nickeson, S. Garrigues, N. Shabanov, M. Weiss, R. Fernandes, S. Leblanc, M. Kalacska, G. A. Sánchez-Azofeifa, M. Chubey, B. Rivard, P. Stenberg, M. Rautiainen, P. Voipio, T. Manninen, A. Pilant, T. Lewis, J. Iiames, R. Colombo, M. Meroni, L. Busetto, W. Cohen, D. Turner, E. D. Warner, G. W. Petersen, G. Seufert, and R. Cook, "Validation of global moderate-resolution LAI products: A framework proposed within the CEOS Land Product Validation Subgroup," IEEE Trans. Geosci. Remote Sens., vol. 44, no. 7, pp. 1804-1817, Jul. 2006. 

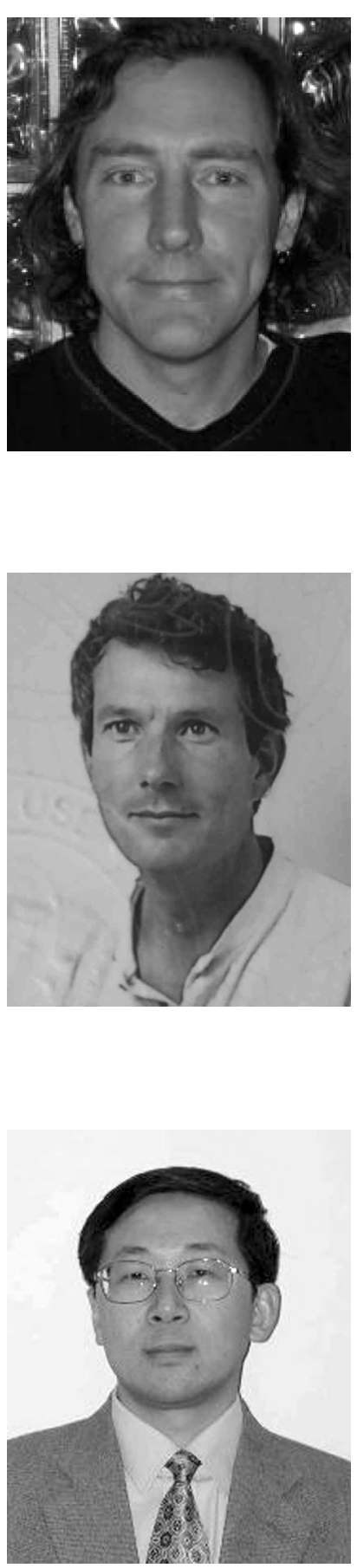

Jeffrey T. Morisette received the M.S. degree in statistics from Oakland University, Rochester, MI, and the Ph.D. degree from North Carolina State University, Raleigh, in 1992 and 1997, respectively. He also attended the International Space University's Summer Program, Vienna in 1996.

He helped establish the CEOS "Land Product Validation Subgroup," serving as Deputy-Chair from its inception in 1999 to 2002, and Chair from 2003 to 2006. He is currently a member of NASA's MODIS science team, serving as the Land Product Validation Coordinator.

Frédéric Baret received the Ph.D. degree in 1986 on the application of remote sensing to agriculture.

Since that time, he has been working at the National Institute of Agronomical Research, focusing on radiative transfer modeling in the solar domain, estimates of canopy and soil characteristics from radiometric observations, and assimilating these data into canopy functioning models. He was also coordinating large experiments such as Alpilles-ReSeDA, ADAM, and is currently in charge of the VALERI and CYCLOPES projects for the development and validation of medium-resolution satellite products.

Shunlin Liang received the Ph.D. degree in remote sensing and GIS from Boston University, Boston, MA, in 1993.

He was a Postdoctoral Research Associate in Boston University from 1992 to 1993, and Validation Scientist of the NOAA/NASA Pathfinder AVHRR Land Project from 1993 to 1994. He is currently an Associate Professor in the University of Maryland, College Park. His research interests focus on land surface data assimilation and quantitative optical remote sensing. He is a member of NASA ASTER, MISR, and MODIS science teams. He is the author of Quantitative Remote Sensing of Land Surfaces (Wiley, 2004).

Dr. Liang is Co-Chairman of the International Society for Photogrammetry and Remote Sensing Commission VII/WG1 on Fundamental Physics and Modeling. He is an Associate

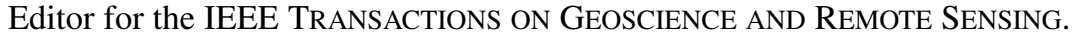

